\title{
Species diversity and community structure of butterfly in urban forest fragments at Lucknow, India
}

\author{
Ashok Kumar* \\ Department of Zoology, BSNVPG College (Lucknow University), Lucknow (U.P.), India \\ Satyapal Singh Rana \\ Department of Zoology, S. M. P. Govt. Girls P.G. College, Meerut (U.P.), India \\ ${ }^{*}$ Corresponding author. E-mail: ashokbsnv11gmail.com
}

\section{Article Info}

DOI:10.31018/jans.v10i4.1908 Received: September 26, 2018 Revised: November 18, 2018

Accepted: November 27, 2018

\section{How to Cite}

Kumar, A. and Rana, S.S. (2018). Species diversity and community structure of butterfly in urban forest fragments at Lucknow, India. Journal of Applied and Natural Science, 10 (4): $1276-1280$ net, which were then placed in killing jar. Killed butterflies were stored in the insect box by proper pinning them for identification. During the course of study, 30 species of butterflies, belonging to 26 genera, representing 5 families, were recorded in Lucknow. 11 Species from nymphalidae, $7 \mathrm{sp}$. pieridae, $5 \mathrm{sp}$. from lycaenidae, $3 \mathrm{sp}$. From hesperidae and $3 \mathrm{sp}$. from papilionidae were recorded in all selective sites. The butterflies observed were categorized into groups based on their relative numbers; most common $>9-10$, common $6-8$, rare $3-5$, very rare $0-2$. This study is used for academic as well as applied importance.

Keywords: Butterfly, Species diversity, Community structure, Urban, Forest fragments

\section{INTRODUCTION}

There are over one million known species of insects in the world and some experts estimate that there might be as many as 10 million. Lepidoptera is a very large order under Class Insects that includes some of the most beautiful species and many economically important pests. Many schemes of classification exist for the Lepidoptera.

Butterflies have been studied systematically since the early $18^{\text {th }}$ century and 19,238 species had been documented worldwide (Heppner, 1998). This figure is not constant because of the continuous discovery of new butterflies (Lewis, 1973; Stokoe, 1974; Mani, 1986; Godden, 1997; Green and Huang, 1998; Barua et al, 2004; Ambrose et al, 2005; Xavier, 2006; Chandra et al, 2007; Parag and Omkar 2009), and also due to ongoing disagreements between taxonomists over the status of many species. The resources such as host plants and food sources for butterflies available in grassy areas make them indispensable sites for their survivor and consequently for our survey. Kumar, 2012; 2014; 2017 and Saveena
Bogtapa, 2015 total of species 27 belonging to family, 38 species belonging to 6 family, 38 species belonging to 6 family and 105 species belonging to 5 family were detected from different sites of Jhansi and Solan Himachal Pradesh. Pandhye et al. (2012) recorded a total 334 species belonging to 6 family and 164 genera from Western Ghats of India.

The distribution of butterflies involves both expanding and contracting ranges, but natural changes in the distribution of species can be difficult to deduce because they tend to be slower and subtler than the dramatic changes caused by man. Unfortunately, most expanding ranges involve introduced species and most contracting ranges are due to the destruction of natural habitats (Lafontaine, 1997). Expansion in a species range may often be in response to human activities favoring these species, making these butterflies opportunists. In order to document such temporal changes over time, a baseline faunal inventory must first be established. The real position of butterfly population particularly of all selected sites is still not clearly known due to lack of proper study. The present study was conducted to study 
Kumar, A. and Rana, S.S. / J. Appl. \& Nat. Sci. 10 (4): 1276-1280 (2018)

distribution and diversity of butterflies in all five habitats of Lucknow region for the first time.

\section{MATERIALS AND METHODS}

Butterflies were observed throughout the year from September 2015- August 2016 in five respective sites of Lucknow. These five sites were selected on the basis of their position in vegetation and accessibility. The first site, Bijli Pasi Quila is situated near the Quila Chauraha Aashiyana. The flora present there provides support and favorable conditions for flying birds; especially our national bird peacock; and for beautiful butterflies. Second site, Smriti Upvan is known for jogging and huge green lawns which support butterflies and other animals. It has vast variety of plants and trees which provide shelter for different species of butterflies. Third site, Vanasthali Park was made by Uttar Pradesh government primarily for walking. It comprises various forms of flowering plants, wild plants and ornamental plants; and provides healthy environment for butterflies and other insects. Fourth site, Butchery Ground is located in southern side of Lucknow. This site extends up to $2 \mathrm{~km}$ and is rich in ornamental and wild plants providing site for butterflies nectaring and egg lying. Fifth site, campus of the BSNVPG. College Lucknow is small but some area has green vegetation which provide favorable conditions for insects. There are wild and ornamental plants which attract the butterflies as well as other insects (Fig.1).

Each site was sampled from 8 am to11 am at intervals of 2 or 3 days throughout the study period. Butterflies resting on plants and those in flight were counted and identified. If an exact determination of the species was not possible, an insect sweep net was used to capture those butterflies in question to facilitate field identification. Only those species that could not be identified in the field were killed and brought to the laboratory and their wings were spread on the spreading board. These butterflies were stored in insect box by pinning them and were later identified in the laboratory using the available literature (Wynter-Blyth 1957; Makris, 2003; Kunte, 1996, 1997 and 2000; and Tolman and Lewington, 1997).

\section{RESULTS AND DISCUSSION}

In the present study, six hundred and forty three species of butterflies belonging to 5 families of 26 genera collected from five study sites of Lucknow are given in Tables1 and 2. The family Nymphalidae was the most common followed by Pieridae, Lycaenidae, Hespiridae and then followed by $\mathrm{Pa}-$ pilionidae family.

In Nymphalidae family, eleven species, Common leopard Atella phalanta, Lemon pansy Precis lemonias, Blue pansy Precis orithya, Yellow pansy

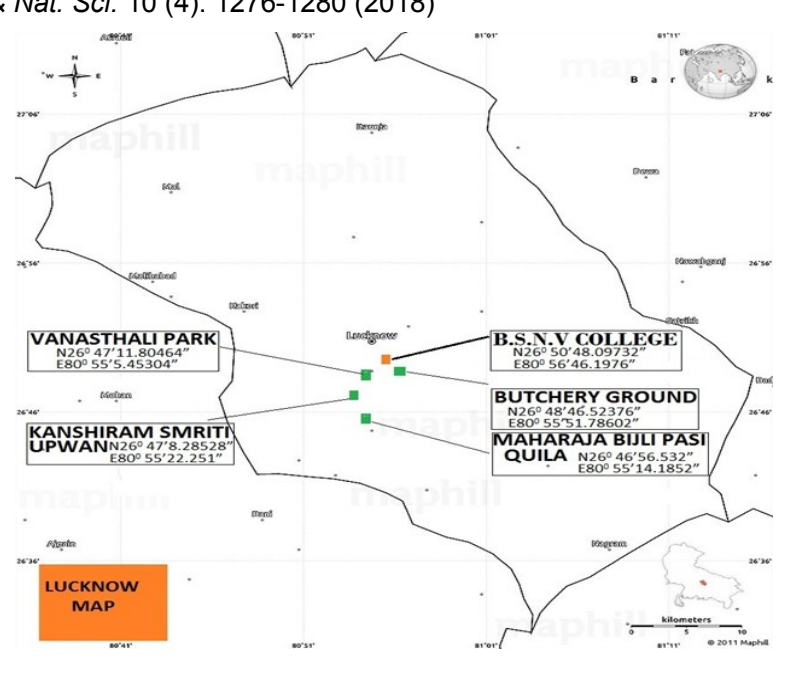

Fig. 1. Diagrammatic representation of butterfly study sites of Lucknow region.

Precis hierta, Blue tiger Tirumala limniace, Danaid egg fly Hypolimnas missipus, Striped tiger Danaus genutia, Plain tiger Danaus chrysippus, Common core Euploea core and Common castor Ariadne merione, Common evening brown Melanitis leda; were recognized.

In Pieridae family seven species were identified, White orange tip Ixias marianne, Mottled emigrant Catopsilia pyranthe, Small grass yellow Eurema brigitta, Small cabbage white Pieris rapae, Common emigrant Catopsilia crocale, Pioneer Anaphaeis aurota, Common gull Cepora Nerissa and Large salmon arab Colotis fausta. The Lycaenidae family had five species; Small cupid Chilades contracta, Lesser grass blue Zizina otis, Forget me not Catochrysops strabo, Pea blue Lampides boeticus and Rounded pierrot Tarucus extricatus. In Hespiridae family, three species Grass Demon Udaspes folus, Dark Palm Dart Telicota ancila and Common Grass dart Tatractrocera maevius while in Papilionidae family three species, Lime butterfly Papilio demoleus, Common rose Atrophaneura aristolochiae Tailed jay Zetides agamemnon were identified The Bijli Pasi Quila appears to show most species richness ( $n=151,23.48 \%)$ with 26 genera followed by Vanashthali Park and Butchery Ground $(n=136,21.15 \%$ with 22 genera and $\mathrm{n}=132,20.52 \%$ with 25 ) respectively. In Smriti Upvan and BSNVPG College, there was lower species richness $(n=120,18.66 \%$ and $n=104$, $16.17 \%$ ) (Table 2)

The commonly seen butterflies in the five selected sites were Small grass yellow (Eurema brigitta), White orange tip (Ixias Marianne), Blue pansy (Precis orithya), Blue tiger (Tirumala limniance), Striped tiger (Danaus genutia), Plain tiger (Danaus chrysippus), Common crow (Euploea core), Mottled emigrant (Catopsilia Pyranthe), Common emigrant (Catopsialia crocale), Pioneer (Anaphaeis aurota), Common gull (Cepora neris- 
Table 1. Butterfly species in different study sites of Lucknow region.

\begin{tabular}{|c|c|c|c|c|c|c|c|c|}
\hline S.N. & Family/Genera/Species & Common Name & $\mathrm{BPQ}$ & SU & VP & BG & CC & Abundance \\
\hline & Nymphalidae / 8 / 11 & & & & & & & \\
\hline 1 & Atella phalanta & Common leopard & 3 & 1 & 4 & - & 1 & $\mathrm{R}$ \\
\hline 2 & Precis lemonias & Lemon pansy & 2 & - & 7 & 2 & 2 & $\mathrm{R}$ \\
\hline 3 & Precis orithya & Blue pansy & 2 & 4 & 2 & 7 & 4 & C \\
\hline 4 & Precis hierta & Yellow pansy & 2 & 1 & - & 1 & 2 & $\mathrm{R}$ \\
\hline 5 & Tirumala limniace & Blue tiger & 4 & 2 & 2 & 4 & 3 & C \\
\hline 6 & Hypolimnas missipus & Danaid eggfly & 2 & 1 & - & 2 & 1 & $\mathrm{R}$ \\
\hline 7 & Danaus genutia & Striped tiger & 6 & 2 & 4 & 5 & 4 & C \\
\hline 8 & Danaus chrysippus & Plain tiger & 7 & 4 & 5 & 2 & 4 & C \\
\hline 9 & Euploea core & Common crow & 7 & 6 & 16 & 7 & 6 & C \\
\hline 10 & Ariadne merione & Common castor & 1 & - & 2 & 1 & 1 & V.R. \\
\hline 11 & $\begin{array}{l}\text { Melanitis leda } \\
\text { Pieridae / } 7 \text { / } 8\end{array}$ & Common evening brown & 2 & 1 & 3 & 2 & - & V.R. \\
\hline 12 & Ixias marianne & White orange tip & 20 & 18 & 16 & 13 & 10 & M.C. \\
\hline 13 & Catopsilia pyranthe & Mottled emigrant & 1 & 4 & 3 & 2 & 2 & C \\
\hline 14 & Eurema brigitta & Small grass yellow & 35 & 38 & 33 & 29 & 20 & M.C. \\
\hline 15 & Pieris rapae & Small white & 2 & - & 2 & 2 & 1 & $\mathrm{R}$ \\
\hline 16 & Catopsilia crocale & Common emigrant & 5 & 2 & 2 & 4 & 3 & C \\
\hline 17 & Anaphaeis aurota & Pioneer & 9 & 3 & - & 3 & 4 & $\mathrm{C}$ \\
\hline 18 & Cepora nerissa & Common gull & 6 & 6 & 7 & 7 & 5 & $\mathrm{C}$ \\
\hline 19 & $\begin{array}{l}\text { Colotis fausta } \\
\text { Lycaenidae / } 5 \text { / } 5\end{array}$ & Large salmon arab & 2 & 3 & 1 & 2 & 2 & $\mathrm{C}$ \\
\hline 20 & Chilades contracta & Small cupid & 7 & 3 & 2 & 3 & 2 & C \\
\hline 21 & Zizina otis & Lesser grass blue & 3 & 1 & 2 & 4 & 3 & $\mathrm{R}$ \\
\hline 22 & Catochrysops strabo & Forget me not & 2 & 1 & - & 4 & 3 & $\mathrm{R}$ \\
\hline 23 & Lampides boeticus & Pea blue & 1 & 2 & 1 & 4 & 4 & $\mathrm{R}$ \\
\hline 24 & $\begin{array}{l}\text { Tarucus extricates } \\
\text { Hespiridae / } \mathbf{3} / \mathbf{3}\end{array}$ & Rounded pierrot & 3 & 1 & 1 & 2 & 2 & $\mathrm{R}$ \\
\hline 25 & Udaspes folus & Grass Demon & 2 & 1 & 2 & 1 & 2 & $\mathrm{R}$ \\
\hline 26 & Telicota ancila & Dark Palm Dart & 3 & 2 & 3 & 2 & 2 & $\mathrm{R}$ \\
\hline 27 & $\begin{array}{l}\text { Tatractrocera maevius } \\
\text { Papilionidae / } \mathbf{3} / \mathbf{3}\end{array}$ & Common Grass dart & 3 & 2 & 3 & 2 & 1 & $\mathrm{R}$ \\
\hline 28 & Papilio demoleus & Lime butterfly & 5 & 6 & 8 & 7 & 5 & C \\
\hline 29 & Atrophaneura aristolochiae & Common rose & 2 & 2 & 3 & 2 & 1 & V.R. \\
\hline 30 & Zetides agamemnon & Tailed Jay & 2 & 3 & 2 & 2 & 3 & $\mathrm{R}$ \\
\hline
\end{tabular}

Abbreviations: BPQ - Bijli Pasi Quila; SU - Smriti Upvan; VP - Vanasthali Park; BG - Butchery ground; CC- College Campus; MC-Most common; C-Common; R-Rare; VR - Very Rare

Table 2. Total number and percentage of genera and species in different sites of Lucknow.

\begin{tabular}{|c|c|c|c|c|c|}
\hline S.N. & Sites & $\begin{array}{ll}\text { Numbers/Percentage } & \text { of } \\
\text { Butterflies } & \\
\end{array}$ & $\begin{array}{ll}\text { Numbers/Percentage of } \\
\text { Genera }\end{array}$ & $\begin{array}{l}\text { Numbers/ } \\
\text { of species }\end{array}$ & Percentage \\
\hline 1 & $\mathrm{BPQ}$ & $151 / 23.48$ & $26 / 100$ & $30 / 100$ & \\
\hline 2 & SU & $120 / 18.66$ & $23 / 88.4$ & $27 / 90$ & \\
\hline 5 & VP & $136 / 21.15$ & $22 / 84.6$ & $26 / 86.6$ & \\
\hline 4 & $B G$ & $132 / 20.52$ & $25 / 96.1$ & 29/96.6 & \\
\hline 5 & $\mathrm{CC}$ & $104 / 16.17$ & $25 / 96.1$ & 29/96.6 & \\
\hline & Total & 643 & 26 & 30 & \\
\hline
\end{tabular}

Table 3. Anthropogenic activities in different sites of Lucknow.

\begin{tabular}{lll}
\hline S.N. & Sites & Activities \\
\hline $\mathbf{1}$ & BPQ & Visitors (Morning and Evening walkers ), insectivore birds, Noise and dust pollution \\
$\mathbf{2}$ & SU & Visitors (Morning and Evening walkers ), insectivore birds, Noise and dust pollution \\
$\mathbf{3}$ & VP & Visitors (Morning and Evening walkers ), insectivore birds, Noise and dust pollution \\
$\mathbf{4}$ & BG & Army activities, transport, noise, dust pollution and insecticide \\
$\mathbf{5}$ & CC & Students, Teaching, Non-teaching Staff, Noise and insecticide \\
\hline
\end{tabular}

sa), Large salmon arab (Colitis fausta), Small cupid (Chilades contracta), Lime butterfly (Papilio demoleus), but the most abundant species was Eurema brigitta (Pieridae) while Ixias Marianne (Pieridae) was the next most abundant species in all collected species. Small grass yellow Eurema brigitta, white orange tip Ixias Marianne were the most common butterflies in all sites. The species Précis orithya, Tirumala limniace, Danaus genutia, Danaus chrysippus, Euploea core, Catopsilia pyranthe, catopsilia crocale, Anaphaei aurota, Cepora nerissa, colitis fausta, chilades contracta, 
appilio demoleus are common butterflies. Atella phalanta, Precis lemonias, Precis hierta, Hypolimnas missipus, Pieris rapae, Zizina otis, Catochrysops strabo, Lampides boeticus, Tarucus extricatus rare butterflies. Atrophaneura aristolochiae, Abisara echerius, Ariadne merione, Melanitis leda were very rare butterflies (Table 1).

The diversity of butterflies in Lucknow could be attributed to the evergreen forest of study sites at low altitude that receives fairly good rainfall and experience only a brief period of dryness. The diversity of butterflies was found poor where anthropogenic activities have been taking place. The butterfly fauna of study sites may be affected and endangered by some anthropogenic activities including land use, forest cultivation and plant protection, jogging, walking, noise and insecticide used (Table 3). Hence, prevention of habitat fragmentation and destruction, regulation of government, avoidance of insecticide and greenery management etc. in sites and general awareness programme arranged for people could help in conservation of species.

Certain species of Lepidoptera are serious pests of ornamental plants, trees, capable of destroying entire plantations. In some cases only the application of pesticides may prevent major damage to plants and trees. Pesticide applications are widely believed to be a necessary element of greenery management. The study sites had various habitats ranging from natural forest to gardens and plantation. The butterfly diversity was also varied in these habitats but the pattern of variation was different. Present study revealed that although at undisturbed and wild sites there was less species richness, they were the excellent sites for the occurrence of unique species. In disturbed habitats and human impacted sites, species richness was increased but the uniqueness was less. These observations are in good agreement with Padhey et al., 2006; Kunte 2001; Tiple et al., 2007; Kumar, 2011; 2012; 2014; 2017 and Saveena Bogtapa, 2015 stating that impact zones are richer in species richness. When comparison was made at different sites under investigation, highest number of species were recorded from BPQ and BG (30 and 29) while least number of species (22) from VP. Earlier studies on butterfly species diversity of some cities in India indicates that comparatively Jhansi city had poorest butterfly diversity of $23 \mathrm{Sp}$. (Kumar, 2011) than the cities like Pune with 103 Sp. (Kunte, 997); metropolitian Delhi $86 \mathrm{Sp}$. (Larsen, 2002); Visakapatnam 68 Sp. (Solmanraju, 2004), Solan HP 105 Sp. (Saveena Bogtapa, 2015) and Amravati 52 Sp. (Tiple et al., 2006). The butterfly fauna of Nagpur city of central India is very rich with 145 Sps. (Tiple, 2009). The members of nymphalidae, pieridae, lycaenidae and papilionidae reported in Lucknow have also been reported in Nagpur city. The diversity of but- terfly decreases from south towards north, i.e., Kerala (314sps.), Karnataka (316sps.), TamilNadu (316), Goa (249sps.), Maharashtra (208), and is the lowest in Gujarat (158) sps (Gaonkar, 1996) Monthly data for the spring-summer of 2016 indicate that the greatest number of species and numbers of butterflies observed was during May with a gradual falling off of numbers as the summer progressed. This is an expected pattern for a Mediterranean climate because the peak period of flower activity occurs in April-May with a gradual decline in the number of plants flowering as the dry season progresses and herbaceous vegetation cures. Consequently the number of nectar sources available for the butterflies declined. This pattern was more apparent in the plantations than in the mature forests for the families Nymphalidae, Pieridae and Lycaenidae and the most commonly occurring species.

\section{Conclusion}

This study is first of its kind in these sites. The population of butterfly is very less in two sites i.e. BSNVPG College, Lucknow and Butchery ground due to the more disturbance and anthropogenic activity and in remaining three sites (Bijli Pasi Quila, Smriti Upwan and Vansthali Park) butterfly diversity and population are satisfactory because there were less disturbance and more vegetation. This suggests that more study and proper strategies are needed for suitable conservation of butterfly in all these sites.

\section{REFERENCES}

1. Ambrose P. Dunston and Raj D. Senthil (2005). Butterflies of kalakad- mundanthurai tiger reserve, Tamil Nadu. Zoos'Print Journal, 20 (12): 2100-2107.

2. Pandhye, A., Shelke, S. and Dhahnukar,N. (2012). Distribution and composition of butterfly species along the latitudinal and habitat gradients of the Western Ghats. Check list, 8(6):1196-1215.

3. Barua K.K., Kakati D. and Kalita J. (2004). Present Status of Swallowtail butterflies in Garbhanga reserve forest, Assam, India. Zoos'Print Journal.19 (4):14391441.

4. Chandra K., Sharma R.M., Ajit Singh and Singh R.K. (2007). A checklist of butterflies of Madhya Pradesh and Chhattisgarh States, India. Zoos'Print Journal.22 (8):2790-2798.

5. Godden, R. (1997). The Wonderful World of Butterflies and Moths. Hamlyn Pub. Group Ltd., London: 96

6. Green, J. and Huang, A. (1998). Butterflies of South Vancouver Island. Co-op resort. Royal British Columbia Museum. Available Online at: http:// rbcm.gov.bc.ca/nh-papers/anneh/text/coverpage.html

7. Heppner, J. (1998). Classification of Lepidoptera. Part1 Introduction. Holarctic.Lep.Vol.5, Supplement $1: 148$

8. Kumar, A. (2011). A study on butterfly abundance and diversity in Jhansi, Uttar Pradesh, India. The biosphere, 3(1):45-48

9. Kumar, A. (2012). A report on the butterfly in Jhansi, (U. P.), India. Journal of applied and Natural Science 
4(1): 51-55.

10.Kumar, A. (2014). Butterfly abundance and species diversity in some urban habitats. International Journal of Advance Research, 2 (6): 367-374.

11.Kumar, A. (2017). Species diversity and distribution of butterfly fauna with heterogeneous habitats in Jhansi, India. Int. J. Adv. Res. Biol. Sci., 4 (7): 104110.

12.Kunte, K. J. (1997). Seasonal Patterns in the Butterfly Abundance and Species Diversity in Four Tropical Habitats in Northern Western Ghats. J. Biosci., 22 (5): 593-603

13.Kunte, K.J. (1996). Strange Behaviour of Mottled Emigrant male. Journal Bombay Natural History Society, 3(2): 307-308

14.Kunte, K.J. (2000). India a Lifescape Butterflies of Peninsular India. Universities Press (India) Limited.

15.Kunte, K.J. (2001). Butterfly diversity of Pune city along the human impact gradient. J. Ecol. Soc., 13/14: 40-45.

16.Lafontaine, J.D. (1997). Butterflies and Moths. In Smith, I.M. (ed.).Assessment of Species Diversity in the Mixedwood Pains Ecozone. Printed Summary [1997]. Eman Publication: 31 + CDROM

17.Larsen, T.B. (2002). The butterflies of Nilgiri mountain of southern India (Lepidoptera: Rhopalocera). Journal of Bombay Natural history Society, 85 (1) : 30-43.

18.Lewis, H.I. (1973). Butterflies of the world. Harrap. London.

19.Makris, C., (2003). Butterflies of Cyprus. Published by Bank of Cyprus Cultural Foundation,

20.Mani, M.S. (1986). Butterflies of Himalaya. New Delhi, India .Oxford IBH Publishing Co.Nicosia, 327 pp.

21.Padhey, A.D., Dahanukar, M., Paigankar, M.,Deshpande, M. and Deshpande, D. (2006). Sea- son and landscape wise distribution of butterflies in Tamhini, Northern western Ghats India, Zoos'Print Journal, 21:2175-2181.

22.Parag E. and Omkar D. (2009). Three additions to the known butterfly ( Lepidotera: Rhopalocera and Grypocera) fauna of Goa, India. Journal of Threatened Taxa 1(5): 298-299.

23.Saveena Bogpata (2015). Diversity of butterflies from District Solan Himachal Pradesh,India. Journal on New Biological Report, 4(2) : 139-148.

24.Solmanraju,A.J.(2004). Nector host plants of some butterflies species at Visakapatnam. Sci. and Cul., 70: $187-190$.

25.Stokoe, W.J. (1974). The Observer's Book of Butterflies. W.J. Frederick Warne and Co., London: 191

26.Tiple, A.D. (2009). Butterflies from Nagpur city, central India: Diversity, Population, nector and larval plants and the implications for conservation, $\mathrm{PhD}$ Thesis, RTM Nagpur University Nagpur India 1-146.

27.Tiple, A.D., Deshmukh,V.P. and Dennis R.L.H. (2006). Factors influencing nector plants resource visit by butterfly on a university campus: implication for conservation. Nota Lepid., 28 213-224.

28.Tiple, A.D., Khurad, A.M. and Dennis R.L.H. (2007). Butterfly diversity in relation to a human impact gradient on Indian university campus. Nota Lepid., 30 (1);179-188.

29.Tolman, T., Lewington, R., (1997). Butterflies of Europe. Princeton and Oxford, U.K.,

30.Wynter-Blyth, M.A. (1957). Butterflies of the Indian Region. Bombay Natural History Society, CME Press Poona.

31.Xavier, A. (2006). Butterfly fauna of Government arts and Science College campus, Kozhikode, Kerala. Zoos' Print Journal.21 (3): 2263-2264. 